\title{
9. レーザイメージャの画像処理機能の検討
}

\author{
A STUDY OF LASER IMAGER \\ WITH IMAGE PROCESSING FUNCTION
}

\section{滋賀医科大学附属病院故射線部}

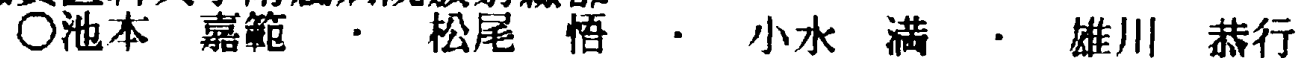

(Yoshinori Ikemoto) (Satoru Matsuo)(Mitsuru Komizu) (Yasuyuki Ogawa)

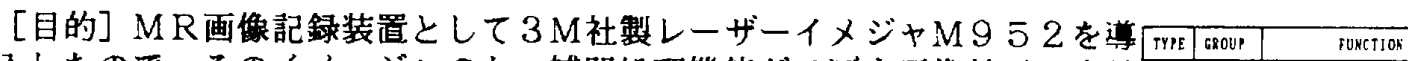
入したので、そのイメージャのもつ補間処理機能が及ぼす画像効果を定量 評価し、䀦床上妥当な処理を見いだすことを目的とした。

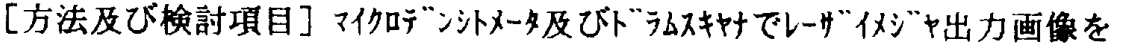
デジタ多化しFig-1示した16種のモードについて下記の項目を検討評価した。 $\diamond$ 鮮鋭度に及ほす影整の程度 <FWHM 評価 $><F$ i g - 2>

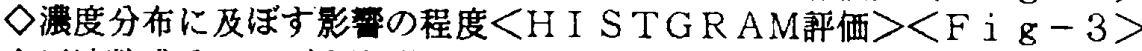
$\diamond$ 周波数成分に及ぼす影繁程度 $<2$ DFF T 評価 $><F$ i g - 4 , 5> $\diamond$ 画像面皘に及ぼす影響の程度 $<$ GRADI E N T評価 $><$ F i g-6>

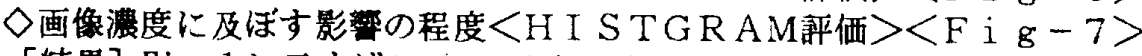

\begin{tabular}{|c|c|c|}
\hline 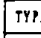 & 68004 & Function \\
\hline E & $6-1$ & 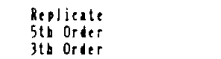 \\
\hline & $G-2$ & 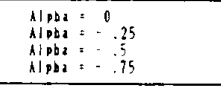 \\
\hline 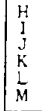 & $G-3$ & 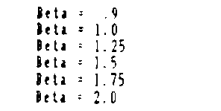 \\
\hline p & $G-4$ & 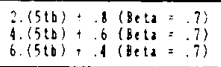 \\
\hline
\end{tabular}

[結果] Fig-1に示すグルーブー1 は多項式関数補間、2 と 3 はスプライン関数補間、4はそれらの組合せ補間 を示す。特にTYPE-Aは無処理のREPLACEモードである。 FWHMで評価するとG 1 とG 4 が解鋭度に優れ $\mathrm{G} 2$ とG 3 は劣る。また、ヒ訃グ弘分布の標準偏差で濃度分布を 評価すると、G 3 のTYPE-K,L,M低值を示し、謴度分 布のばらつきを小さくする処理効果があると言える。 一方G 4 のTYPE-N, 0,Pは高俻を示し、濃度分布のばら つきを大きくすると言える。また、2 次元F F T処理 を行い周波数成分の分布を評価すると、REPLACEモードと 比較してTYPE-Kでは基本周波数から2.51p/mmまでの成 分が低値を示し平滑化の程度が大きくなり、TYPE-Nで は高值を示し、鲜鋭化の程度が高い処理効果を持つと 言元る。Fig-6は、面積比別に最大 $\gamma$ 値を算出した表で 明らかにサイズ効果が出ている。Fig-7から、高蕽度に なるに従い処理効果が出ている。

\section{[結論]}

○画像面積が大きくなる程、処理の影製は大きくなる。 ○処理によりイメージャ設定濃度を変える必要がある。 ○SMOOTHモードとしては、スプライン関数補間するも のが、妥当である。

○SHARPモードとしては、多項式補間とスプライン関数 補間の組合せモードが、妥当である。
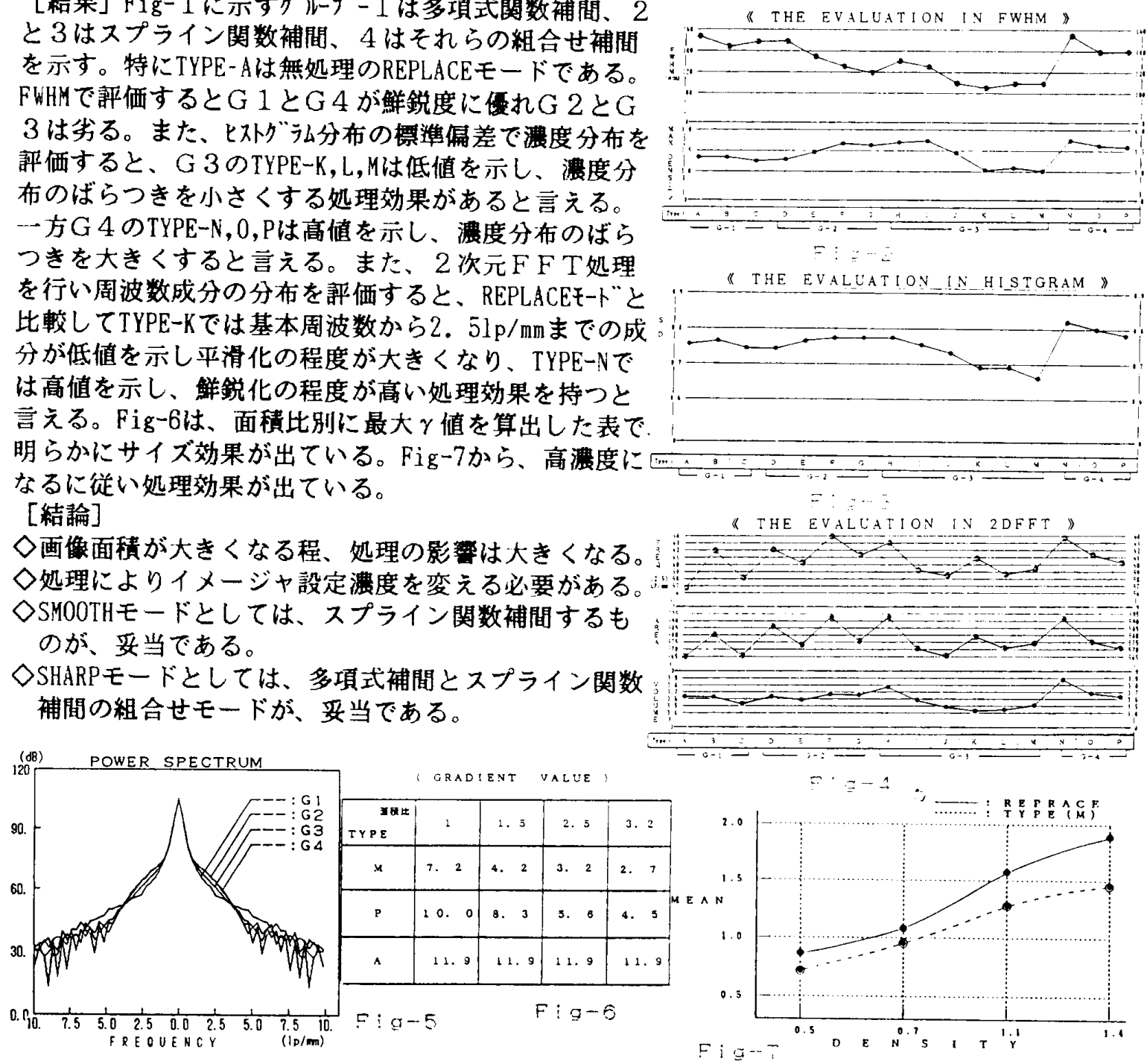